\title{
Sovereignty through the Inter-Disciplinary Kaleidoscope
}

\author{
Ignacio de la Rasilla del Moral *
}

Hent Kalmo and Quentin Skinner (Eds.) Sovereignty in Fragments. The Past, Present and Future of a Contested Concept (Cambridge University Press, 2011)

Joel P. Trachtman, The Future of International Law. Global Government (Cambridge University Press, 2013)

Timeo hominem unius libri Saint Thomas of Aquinas

\section{Introduction}

In the beginning was ... state sovereignty, or so the oft-quoted statement by the International Court of Justice according to which "state sovereignty" is "the fundamental principle" (...) "on which the whole of international law rests" 1 appears to indicate. There is a remarkable circularity at play between this now classic statement of the principal judicial organ of the United Nations and the fact that Western international lawyers often use the etiological myth (that is, a myth for the origins of things) of Westphalia ${ }^{2}$ to retrace the very origins of their discipline to the emergence of the concept of state sovereignty itself. It comes, thus, as no wonder that in the early stages of the 21 st century, when international law is portrayed in leading textbooks, as "an ubiquitous presence in global policy-making and in academic and journalistic commentary", ${ }^{3}$ international lawyers continue to speculate about the locus classicus of their discipline. The reaffirmation of the state-centric basis of the term coined by J. Bentham ${ }^{4}$ in 1789 , which became widely employed on the occasion of the independence of the new Latin-American Republics from the Spanish Empire in the 1810s and 1820s, benefited greatly from this early association between sovereignty and post-colonial independence. ${ }^{5}$ It was in one of the new independent American Republics, Colombia, where the first ever chair of "international law" (or to use the original language, Derecho internacional) was established. This chair was occupied in 1827 by Ignacio de Herrera Vergara who, therefore, became the very first chair-holder of international law

\footnotetext{
* University Lecturer in Law, Brunel Law School (Brunel University London). FHEA, LLB (U.C. Madrid), MA \& Ph.D. (IUHEID, Geneva) LLM (Harvard). In the Spring and Summer of 2014, Visiting Scholar, Lauterpacht Research Centre for International Law (University of Cambridge) and Max Planck Institute for European Legal History in Frankfurt.

1 Military and Paramilitary Activities (Nicaragua v. United States of America), Merits [1986] ICJ Rep 14, at para. 263.

2 S Beaulac, The Power of Language in the Making of International Law: The Word Sovereignty in Bodin and Vattel and the Myth of Westphalia (Brill, 2004)

$3 \mathrm{~J}$ Crawford and M Koskenniemi (eds) Cambridge Companion to International Law (Cambridge UP, 2011)

$4 \mathrm{~J}$ Bentham, An Introduction to the Principles of Morals and Legislation (1789). For a commentary, see MW Janis, "Jeremy Bentham and the Fashioning of International Law", 78 American Journal of International Law (1984) 405.

5 On International Law and Latin-America after decolonization, see e.g. L Obregón Tarazona "The Colluding Worlds of the Lawyer, the Scholar and the Policymaker: A View of International Law from Latin America", 23 Wisconsin International Law Journal (2005) 145 and A Becker Lorca "International Law in Latin America or Latin American International Law? Rise, Fall, and Retrieval of a Tradition of Legal Thinking and Political Imagination" 47 Harvard International Law Journal 1 (2006) 283
} 
in the world. This seminal strong linkage between international law and state sovereignty - and its international legal corollaries, that is, the principles of sovereign equality and non-intervention would become even further entrenched when state sovereignty became the symbol for colonial peoples of "the hard-won prize of their own struggle for emancipation"6 during the second great historical decolonization process after the Second World War. The historical cornerstone quality of state sovereignty for international law begins, however, to appear more disputable as soon as one scratches the surface of its post-colonially reinforced apparent inextricability. The state-centric conceptualization of international law - which, perhaps, would be, more coherently, captured within this paradigm, as inter (sovereign)-state law ${ }^{7}$ - appears, indeed, less pronounced in earlier terminological historical usages such as those of ius gentium, ius inter gentes, the law of peoples $^{8}$ or, even, the law of nations. The latter was employed, along with the "law of nature", in the endowment of several chairs in the $18^{\text {th }}$ century following the cross-European influence of $S$. Pufendorf's De lure Naturae et Gentium published in 8 volumes in 1672. The state-centrism of international law was neither present in other partially equivalent terms which stretch far beyond the Latin-European political and intellectual tradition of international law. ${ }^{9}$ These include the Islamic as-Siyar whose first treatise, which dates back to the 9 th century, ${ }^{10}$ is "considered the world earliest treatise of international law as a separate topic". ${ }^{11}$

Whereas contributions to the history of international law have traditionally revolved around the evolving notion of state sovereignty, the latter is, needless to say, very far from being relegated to the history of international law. Far to the contrary, state sovereignty remains the gravitational centre of contemporary international law and it is, as such, explicit in everything contemporary international legal scholarship occupies itself with today. Just since the end of the Cold-War, state sovereignty has been made rhyme with multiple caveats. The notions of "conditional" and "democratic" sovereignty are among those on which more ink has been spilled in international legal scholarship. The notion of "conditional sovereignty" has been gaining momentum pursuant to the early $21^{\text {st }}$ century's fast-track evolution of the notion of "responsibility to protect". ${ }^{12}$ This was filtered, eo nomine for the first time, ${ }^{13}$ in Security Council Res. 197, ${ }^{14}$ which approved a no-fly zone over Libya, ${ }^{15}$ to, almost immediately afterwards, fall down, on the wake of the Syrian

\footnotetext{
${ }^{6}$ M Bedjaoui, Towards a New International Economic Order, (Holmes and Maier, 1979) 123.

7 The rich connotations of this terminological point can in part be found developed in J Fisch, "Peoples and Nations" in B Fassbender and A Peters. The Oxford Handbook of the History of International Law (Oxford UP, 2012) 27

${ }^{8}$ See, interestingly, K Tuori "The Reception of Ancient Legal Thought in Early Modern International Law", in B Fassbender and A Peters. The Oxford Handbook of the History of International Law (Oxford UP, 2012) 1012.

9 See further I De la Rasilla, "Medieval international Law", Oxford Bibliographies of International Law (Ed. A Carty) (2014)

10 For an English translation, see M Khadduri, The Islamic Law of Nations. Shaybani's Siyar, (The John Hopkins Press, 1966)

${ }_{11}$ C Weeramantry, Islamic Jurisprudence: An International Perspective (Palgrave Macmillan, 1988) 130.

12 Since 2009, there is even a journal Global Responsibility to Protect which defines itself as the "premier journal for the study and practice of the responsibility to protect (R2P)" It is accessible here: http://www.brill.com/global-responsibility-protect (last visited June 2014)

13 A precedent following article 42 under Chapter VII can e.g. be found in S/RES/1706 (2006) where the SC recalls its "Res. 1674 (2006) on the protection of civilians in armed conflict, which reaffirms inter alia the provisions of paragraphs 138 and 139 of the 2005 United Nations World Summit outcome document".

14 S.C. Res. 1973, 6, U.N. Doc S/RES/1973 (Mar.17, 2011)

15 The SC Res. 1973 builds upon paras. 138 and 139 of the World Summit Outcome adopted by General Assembly in its Resolution 60/1,2005 by which the assembled heads of state and government declare themselves to be "prepared to take collective action, in a timely and decisive manner, through the Security Council, in accordance with the UN Charter, including Chapter VII, on a case by case basis and in cooperation with relevant regional organizations as appropriate, should peaceful means be inadequate and national authorities manifestly failing to protect their populations from genocide, war crimes, ethnic cleansing and crimes against humanity"
} 
crisis, from its ephemeral rise to the top of the post-1945 UN system of collective security. ${ }^{16}$ The conceptual rise of the notion "responsibility to protect", which had been gradually replacing the notion of "humanitarian intervention" in international legal scholarship since the early years of the $21^{\text {st }}$ century, marked, for some of its proponents, like A Peters, the definitive enshrinement of "humanity" as the "alpha and omega" of sovereignty. ${ }^{17}$ On the other hand, another conceptual combination, which by linking international human rights' protection and sovereignty has also caused rivers of ink to flow, in the post-90ies' international legal scholarship is that of "democratic sovereignty". The attempt to link the full exercise of the external legal attributes of state sovereignty to the existence of democratically legitimized domestic forms of government, which knew of some precedents in the 1930ies, ${ }^{18}$ became apparent in the internationalist liberal trends that left their mark in the scholarship of the first post-Cold War era as well as in the critical retorts that these received in international legal scholarship. Indeed, taking issue with post-1989 liberal trends in international legal scholarship, a renewed intellectual critical approach coined new scholarly labels such as "liberal anti-pluralism" or ${ }^{19}$ "liberal millenarism" 20 to counter-act the liberal internationalism that ensued the fall of the Berlin wall and the disintegration of the Soviet Union. They did so by delving critically in an array of post-cold war theories like the "Kantian theory of international law", ${ }^{21}$ the "democratic entitlement school", 22 "the liberal internationalist dual agenda", 23 "Rawlsian liberalism", 24 "liberal cosmopolitism", 25 or the scholarly positions of noted representatives of the New Haven school, 26 a "method of international law" that also goes by the names of "configurative jurisprudence" and "policy oriented jurisprudence". 27 Among other critical worries, like those regarding the underlying definition of the so-called democratic principle in international law (see e.g. low-intensity democracy, procedural vs substantive types of democracy) and/or the neo-liberal policies and imperial agendas that were being allegedly advanced by the rise of "democratic liberalism in international legal theory", 28 critical approaches to international law also stressed how the addition of a democratic caveat to the principle of state sovereignty affected the legal-formal isonomy of states through the introduction, as

\footnotetext{
16 Notwithstanding its reappearance also in 2011 in SC Res. 1975 (30th March, 2011) regarding Ivory Coast, and in an operational paragraph in Res. 1996 (2011) on South Sudan.

17 A Peters "Humanity as the Alpha \& Omega of International Law" 20 The European Journal of International Law (2009) 513.

18 See e.g. J Barthelemy, "Politique Intérieure et Droit International" (1937) 59 Recueil des Cours de l'Académie de Droit International, at pp. 490-501.

19 G Simpson, Great Powers and Outlaw States Unequal Sovereigns in the International Legal Order (Cambridge UP, 2004).

20 S Marks, "The End of History? Reflections on Some International Legal Theses" 8 European Journal of International Law (1997) 449

21 FR Tesón, "The Kantian Theory of International Law", 92 Columbia Law Review (1992) 53. See also FR Tesón, A Philosophy of International Law (Westview Press, 1998)

22 T M Franck, "The Emerging Right to Democratic Governance", 86 American Journal of International Law (1992) 46.

23 A M Slaughter, Anne-Marie, "International Law and International Relations Theory: A Dual Agenda", 87 American Journal of International Law (1993) 205 ,

24 J Rawls, The Law of Peoples with "The Idea of Public Reason Revisited", (Harvard UP, 1999)

25 KC Tan, "International Toleration: Rawlsian versus Cosmopolitan" 18 Leiden Journal of International Law (2005) 685.

${ }^{26}$ M W Reisman, "Sovereignity and Human Rights in Contemporary International Law" 84 American Journal of International Law (1990) 866. Reisman defended a "contemporary change in content of the term sovereignty", according to which "international law still protects sovereignty but it is, not surprisingly, the people's sovereignty, rather than the sovereigns' sovereignty".

27 For a recollection of studies, see S. McDougal \& H.D.Laswell, Studies in World Public Order. (New Haven Press, 1987)

28 G.Simpson, "Imagined Consent: Democratic Liberalism in International Legal Theory" 15 The Australian Yearbook of International Law (1994) 103.
} 
highlighted by G. Simpson, of "a threshold requirement of law-making at the two levels of inter-state and intra-state legitimacy". ${ }^{29}$

The principle of equivalence of political regimes in international law remains almost a century after it began to attract the interest of international legal scholarship ${ }^{30}$ still the generally accepted normative point de départ for positivist approaches of international law. State sovereignty, despite the post-1989 legacy of epithets, like those of "conditional" or "democratic", to accompany it, also remains over-present in contemporary discussions. ${ }^{31}$ Today, international legal scholars continue to refer to state sovereignty either to vindicate it as an "obscure representative of an ideal against disillusionment with global power and expert rule", ${ }^{32}$ to imagine new epistemological horizons for it beyond the state, ${ }^{33}$ to dispute it in the field of analytic jurisprudence because of what the late $R$. Dworkin considered, in its latest published work, was its untenable association with state-consent, ${ }^{34}$ or in order to propose new ways of ordering and conceptualize it in view of the growing importance of non-state actors as subjects of an international legal order that transitioned from a pre-institutional to an institutionalised form some time ago already. ${ }^{35}$ In fact, everything under the sun of contemporary international law, every case, every international legal reflection, even the most radical and bold departures from state-sovereignty, are still biting around the apparent centrality and intrinsic conceptual inescapability in contemporary international legal scholarship of what L. Henkin called "that S-word" ${ }^{36}$ And, should we trust M. Koskenniemi, one of the contributors to one of the two volumes under review "whatever changes our political and juridical languages may undergo in the foreseeable future, sovereignty will remain part of them". ${ }^{37}$

Sovereignty is, in fact, one of the two core themes that both books under review have in common. If H.Kalmo and Q.Skinner's edited collection Sovereignty in Fragments takes on what the editors call the "master concept of legal and political philosophy",38 J. Trachtman stresses in his The Future of International Law stresses that one of his goals is to account for the acceleration and accentuation of numerous exceptions to the Westphalian paradigm. ${ }^{39}$ Trachtman, who considers the latter phenomenon to be "the central crisis in international law", 40 proposes to influence the future of international law by making use of a social science functionalist paradigm "which accepts that the state is contingent, and that international law tends to constrain - indeed, to mould - the state on the basis of functional efficiency". ${ }^{41}$ The second core-theme that both books share is inter-disciplinarity. Whereas, in Trachtman's book, inter-disciplinarity makes for the very methodological lenses through which the current limitations of sovereignty for international law

\footnotetext{
29 Simpson (1994) 115.

30 E Root "The Effect of Democracy on International Law", in Proceedings of the American Society of International Law (1917), 2-11.

31 Including in its most nationalistic-sovereignistic legal forms, see e.g. I De la Rasilla "The Dilemma of the Three Wise Monkeys? Transnational Legal Sources in Constitutional Interpretation and the US Supreme Court" 4 Transnational Legal Theory 2 (2013), 227-257.

32 M Koskenniemi, "What use for Sovereignty Today?" Asian Journal of International Law, 1 (2011) 61, 70

${ }^{33} \mathrm{~N}$ Tsagourias (ed.) Transnational Constitutionalism: International Law and European Perspectives (2007)

34 R Dworkin, "A New Philosophy for International Law" 41 Philosophy and Public Affairs (2013) 1.

35 D Kennedy, "The Move to Institutions," 8 Cardozo Law Review (1987) 841.

${ }^{36}$ L Henkin, "That "S" Word: Sovereignty, and Globalization, and Human Rights, Et Cetera", 68 Fordham Law Review (1999) 1.

37 M Koskenniemi, "Conclusion: Vocabularies of Sovereignty - The Powers of a Paradox" in H Kalmo and Q Skinner (eds) Sovereignty in Fragments. The Past, Present and Future of a Contested Concept (Cambridge UP, 2011) 222, 222.

${ }^{38} \mathrm{H}$ Kalmo and Q Skinner "Introduction: A Concept in Fragments" in H Kalmo and Q Skinner (Eds) Sovereignty in Fragments. The Past, Present and Future of a Contested Concept (Cambridge UP, 2011) 1, 24

39 J P Trachtman, The Future of International Law, Global Government (Cambridge UP, 2013) 18.

40 lbid., 18

41 lbid.
} 
are examined, the goal, of Kalmo and Skinner's multi-authored collection is in its turn to provide a multi-disciplinary tour de force about the notion of sovereignty to which constitutional lawyers, historians, international lawyers, international relations scholars, political philosophers and legal practitioners contribute. Therefore, inter-disciplinarity appears, in both books, as the kaleidoscope through which (to paraphrase the subtitle of H.Kalmo and Q.Skinner's edited collection) "the past, present and future of a contested concept", is examined.

\section{Sovereignty and its Inter-Disciplinary Contestants}

The editors of Sovereignty in Fragments open their book with an intriguing and stimulatingly complex introito (or prologue). This revolves around the "consubstantially polemical character" 42 of sovereignty as a "contested concept" in both political and legal philosophy. The editors aim, by taking a "parallax view"43 of the concept of sovereignty, at fostering "inter-disciplinary dialogues" (...) and "to create bridges between fields of enquiry which have hitherto been linked by tenuous cross-references (if at all)". ${ }^{44}$ The inter-disciplinary and hybridizing spirit that animates the book is fully embraced by M Koskenniemi. In the conclusive essay to the volume Koskenniemi points to how "an apparently endless epistemological regress" emerges as soon as "the quest for the explanatory authority of a (single) discipline" 45 to tackle sovereignty is addressed. Koskenniemi exemplifies this conceptual whirlwind through reference to the never-ending closure-quality of the circle of deferrals of disciplinary discourse. The latter transit, in an epistemological symphony-like manner, "from law to politics", "from history to sociology", "from sociology to psychology", "from psychology to philosophy" as well as, one is led to assume, vice versa, as well as in any other imaginable combination of disciplinary vocabularies one might brought together to examine the notion of sovereignty.

Several contributors, in harmony with this spirit of fostering inter-disciplinary dialogues, have answered the call for a "more historical approach" to sovereignty. This call is, in the editors' view, justified because no discipline can be blind to the historicity of sovereignty or, to paraphrase, as the editors in their embracement of a genealogical approach to the concept do, H. Laski, "Sovereignty, liberty, authority, personality - these are the words of which we want alike the history and the definition; or rather, we want the history because its substance is in fact the definition". ${ }^{46}$ This critical historical method 47 targets the reification of the present by showing its contingency in the light of what the Kalmo and Skinner call history's "very strangeness, by making us attend to the multiplicity of paths we did not follow". ${ }^{48}$ The bulk of the historically oriented contributions on the concept of sovereignty is represented by the chapters written by Q.Skinner on the sovereign state, D. Baranger on the apparition of sovereignty, P.Pirimae on the Westphalian myth as well as, more tangentially, J. Bartelson and $\mathrm{H}$. Kalmo on, respectively, the just war tradition and state formation in international law.

\footnotetext{
42 H Kalmo and Q Skinner (2011) 24.

43 lbid., 5.

44 Ibid., 24.

45 Koskenniemi (2011) 225.

${ }^{46}$ H Laski, The Foundations of Sovereignty and other Essays (Yale University Press, 1931) 314 (cited by H Kalmo and Q Skinner (2011) 11

47 On the historical method in international law, see e.g. A Orford, "On International Legal Method" 1.1. London Review of International Law (2013) 166 See also Lesaffer, R.C.H, "International Law and Its History: The Story of an Unrequited Love", M Craven, M Fitzmaurice and M Vogiatzi (eds) Time, History and International Law (Martinus Nijhoff, 2004)

48 H Kalmo and Q Skinner (2011) 10.
} 
Q. Skinner, one of the founders of the "Cambridge School" of the history of political thought, 49 offers a genealogical survey of the sovereign state in Anglophone traditions of legal and political thought. 50 He does so by contextualizing how the concept of the "state", which only began to be widely employed in the late $16^{\text {th }}$ century and early $17^{\text {th }}$ centuries in English language, was used in "successive debates about the nature of public power". ${ }^{51}$ The author's aim, in resorting to a contextual genealogy of the conceptual usage of the term "state", is that of re-examining Hobbes' "fictional theory" of the state and study the latter's great influence on the seventeenth and eighteen century's international legal thought. Skinner, who also revisits the conceptual evolution of the "fictional theory" in English political thought throughout the $19^{\text {th }}$ century and $20^{\text {th }}$ centuries, attempts to prove the applicability of his contextualist method of interpretation of the history of political thought to the task of re-imagining "the state in different and perhaps more fruitful ways" ${ }^{52}$ Also engaged in a genealogical pursuit in the history of ideas is D Baranger who seeks to throw light on the way "in which sovereignty has appeared, or rather has been said to appear, in modern political consciousness". ${ }^{53}$ In particular, Baranger's work delves, first, into the discourse of sovereignty in the debates of French légistes such as Bodin, Loyseau or Coquille in the 16th and early $17^{\text {th }}$ centuries and, secondly, on the uses made of sovereignty by Locke and Rousseau in the eighteen century. Focusing on how "marks of sovereignty" are retraced to a common origin in different legal discourses, Baranger applies an approach to "legal concepts in a manner that is usually restricted to empirical objects" 54 in order to uncover the processes underlying the intellectual efforts to construct the notion of unitary sovereignty. The chapters by D. Pirimae and J. Bartelson continue the efforts of previous contributions of reading historical materials through different conceptual lenses. They do so by extending their inquiry into the relationship between sovereignty and iustum bellum, or just war doctrines. On the first hand, Pirimae "engages" the history of international law ${ }^{55}$ by re-examining the Peace of Westphalia as a foundational myth for the discipline of international law. 56 Pirimae differentiates three levels of criticism towards what Beaulac has called the "etiological myth"57 of Westphalia for international lawyers: firstly, a textual criticism; secondly, a criticism based on the historical analysis of the post-Westphalian system and, finally, a critique addressed to the normative idea of sovereignty which disputes whether this "was actually present in seventeenth century thought". 58 Pirimae's examination of $\mathrm{H}$ Grotius' thought is complemented by an analysis of how the normative ideas of early modern European thinkers and jurists were reflected in the actual international practice of that time and age. Bartelson, on the other hand, examines the argumentative presence in contemporary just war theorists - ranging from M. Walzer to $\mathrm{M}$. Doyle - of the implicit social contract underlying the relationship political authority and the legitimate use of force which is a topic that has gained new prominence as non-state actors and new kinds of warfare have

${ }^{49}$ Q Skinner, "Meaning and Understanding in the History of Ideas". 8 History and Theory 1 (1969) 3.

${ }^{50}$ See Q Skinner, "The sovereign state: a genealogy" H Kalmo and Q Skinner (Eds) Sovereignty in Fragments. The Past, Present and Future of a Contested Concept (Cambridge UP, 2011) 26.

51 Skinner (2011) 26.

52 Ibid., 27.

${ }^{53}$ See further, D Baranger "The apparition of sovereignty", in H Kalmo and Q Skinner (eds) Sovereignty in Fragments. The Past, Present and Future of a Contested Concept (Cambridge UP, 2011) 47.

54 Ibid., 49.

${ }^{55}$ For the expression see T Skouteris, "Engaging History in International Law", in D. Kennedy and J.M. Beneyto (eds.), New Approaches to International Law: The European and American Experiences (2012) 99.

${ }^{56}$ See, bibliographically, I De la Rasilla del Moral "History of International Law, 1550-1700" Oxford Bibliographies of International Law (2013) 1.

57 Beaulac (2004)

${ }^{58} \mathrm{P}$ Piirimae, "The Westphalian myth and the idea of external sovereignty", in $\mathrm{H}$ Kalmo and Q Skinner (eds) Sovereignty in Fragments. The Past, Present and Future of a Contested Concept (Cambridge UP, 2011) 64. 
emerged on the international stage. ${ }^{59}$ Bartelson retraces the circular argumentative structure that exists between conceptions of political authority and the right to wage war back to ancient legal and political theory from the writings of Saint Augustine and commentaries to Gratian's decree to the writings of $\mathrm{F}$ de Vitoria, $\mathrm{H}$ Grotius and $\mathrm{E}$ de Vattel. His historical analysis allows him to conclude that contemporary contestations of sovereignty as the sole site of legitimate political authority appear to "restore the default settings of political thought and action" after what he terms a long post-"Westphalian interlude" when the "locus of legitimate authority remained relatively uncontested". 60 The last of the contributors to the historical intellectual evolution of sovereignty is $\mathrm{H}$ Kalmo who engages with a more recent history of international legal thought (from Jellinek to Kelsen and Hart) in his attempt to revisit the classical question to know whether the birth of a new sovereign state is a de facto or a de iure phenomenon in the light of the practice of the new Baltic states after 1989. 61

The interconnectedness of the history of political thought and the history of international legal thought explored by these contributions finds an immediate echo in the contemporary work of historians of international law international lawyers. Indeed, the historical turn in international law has done much to contribute to the greater awareness on the intersecting nature of compartmentalized knowledge as well as to evidence the traditional inter-disciplinary pollination of the history of international law which blends international relations theory and its historical discourse, legal history, the history of ideas and political thought. Moreover, scholarly investigation into the hitherto traditionally underdeveloped field of the history of international law is currently finding new channels of intellectual exploration - movements, collective identities, non-state actors, cultures, events and individuals. The history of international law is, moreover, extending on the wake of on-going intra-disciplinary specialization beyond a still limited set of histories of international legal concepts and institutions. New research on the history of international law is also being gradually developed from a greater diversity of geographical national, regional, even trans-civilizational or encounters'-based - standpoints. Such an enhanced inter-disciplinarization and the increasingly self-perceived independence of the history of international law as a field of intellectual is, furthermore, already impacting the study of the past of the discipline and spurring the emergence of a robust field of comparative international legal history in both regional62and national traditions. ${ }^{63}$ Whereas the turn to the history in international law is opening new channels of scholarly inquiry and fostering the updating of the study of the respective international legal traditions, such an on-going dynamic transformation of the history of international law is, indeed, far from being alien to the European integration process. Aware of the impact of the European process of regional economic and political integration upon contemporary understandings of sovereignty, several chapters of Sovereignty in Fragments tackle, indeed, the evolving fate of sovereignty within what is today's most influential conceptual test-tube for the experimentation with juridical vocabularies in addressing sovereignty.

One is, indeed, bound to agree with the editor's view that "no treatment of the contemporary tribulations of the concept of sovereignty would be complete without an analysis of the European

\footnotetext{
59 J Bartelson, "Double binds: sovereignty and the just war tradition", in H Kalmo and Q Skinner (eds) Sovereignty in Fragments. The Past, Present and Future of a Contested Concept (Cambridge UP, 2011) 81.

60 Bartelson (2011) 95.

61 H Kalmo, "A matter of fact? The many faces of sovereignty" in H Kalmo and Q Skinner (eds) Sovereignty in Fragments. The Past, Present and Future of a Contested Concept (Cambridge UP, 2011) 114.

62 See e.g. A Becker Lorca, "Universal International Law. Nineteenth Century Histories of Imposition and Appropriation" Harvard International Law Journal (2010) 477, 486.

63 See e.g. Y Gamarra \& I De la Rasilla (Eds). Historia del Pensamiento lusinternacionalista español del siglo XX (Thompson Reuters Aranzadi, 2012). See also C. Joerges , N. S. Ghaleigh \& M. Stolleis (eds.) Darker Legacies of Law in Europe: The Shadow of National Socialism and Fascism Over Europe and Its Legal Traditions (2003
} 
Union"64. Moreover, this European academic debate, which is informed by tensions between descriptive, prescriptive and experimental projections and conceptualizations about the future of the EU, and between the numerous nomenclatures which are constantly been put forward in order to apprehend its evolving nature, not only exerts a considerable influence in shaping the political future of the EU itself but also that of other parallel regional processes of integration. Moreover, the EU debate also engenders intellectual frameworks, discourses and vocabularies which often re-germinate within international legal thought and within the study of international organizations, thus favouring a phenomenon of conceptual communicating vessels. The on-going disaggregation of state sovereignty in the EU has been influenced by a juridical vocabulary developed by the now Court of Justice of the European Union. In 1963, the latter took the first step towards the development of the gradually reformed consent-based international treaties that constitute the EU evolving foundation, by characterizing the EU (by then, the European Economic Community) as "new legal order. ${ }^{65}$ Two contributors to Sovereignty in Fragments, N. MacCormick and M.Troper introduce the conceptual transformational possibilities of the processes of on-going transformation, diffusion and transfer of the classical state sovereignty in the EU. A leading contributor to the EU debate, M. Troper revisits in his chapter a plethora of phenomena, ranging from privatization to globalization, that have been argumentatively employed to underpin the vaunted crisis of the sovereign state. He does so in order to confront the puzzle of whether "at the present stage, it is true (...) that the state can no more be characterized as sovereign"66 in the legal sense. Troper, who devotes a particular attention to the process of European construction in his analysis, relies in particular on the French constitutional scholar Carré de Malberg's three meanings of the word "sovereignty" in order to critically examine their respective presence in contemporary legal discourses. The second contributor to the examination of the impact of the European integration process upon the contemporary understanding of sovereignty in Kalmo and Skinner's edited collection is the late N. MacCormick who was a long-standing proponent of the case for the characterization of both the EU and its member states as "post-sovereign entities" and of Europe as a "locus for post-sovereignty". MacCormick characterized the latter as a horizon for "subsidiarity and polycentric democracy in the governance of Europe". ${ }^{67}$ In his chapter, while admitting the purchase of other conceptualizations of sovereignty in the EU framework such as that of late-sovereignty argued by $\mathrm{N}$. Walker, MacCormick examines sovereignty as both a "cluster" and a "contested concept 68 and presents a new version of his case for the post-sovereignty thesis "applied either to the question of internal sovereignty as possessed by parliaments in states, or to external sovereignty in the light of the constitutional order both of the member states and of the Union collectively". ${ }^{69}$ Following on the steps of discussions on the phenomenon of demise of the state and the rise of post-sovereignty in European legal thought, the chapter by P. Praet concerns itself, in its turn, with the possible consequences of this evolving state of affairs for the Rechtsstaat (or rule of law). This, together with democracy, stand, according to this author, as the main "touchstones against which state policies and actions are critically evaluated". ${ }^{70}$ Against this background, P Praet introduces the notion of "optimum sovereignty" which, he suggests, can be "determined by a trade-off between the benefits of

\footnotetext{
$64 \mathrm{H}$ Kalmo and Q Skinner (2011) 18.

65 More than a half-a-century has elapsed since Van Gend en Loos (1963) and Costa/Enel (1964)

${ }_{66}$ M Troper, "The survival of sovereignty" in H Kalmo and Q Skinner (eds) Sovereignty in Fragments. The Past, Present and Future of a Contested Concept (Cambridge UP, 2011) 132 at 133.

67 N MacCormick, "Sovereignty and after" in H Kalmo and Q Skinner (eds) Sovereignty in Fragments. The Past, Present and Future of a Contested Concept (Cambridge UP, 2011) 151.

68 Ibid., 152.

69 Ibid., 168.

70 P Praet, "Prolegomena for the post-sovereign Rechtsstaat", in H Kalmo and Q Skinner (eds) Sovereignty in Fragments. The Past, Present and Future of a Contested Concept (Cambridge UP, 2011) 169.
} 
increased protection of individuals' rights and the costs of heteronomy". ${ }^{71}$ Such a trade-off is presented to a rational actor when he is given the option to choose between safeguarding a legal order's sovereignty or, by contrast, to support its adherence to a supra-national Rechtsstaat as the one embodied by the EU which the author characterizes as one where currently "certain core elements of the rule of law are (not) upheld" ${ }^{72}$ In this scenario, a rational decision-maker would, according P.Praet, ultimately base its decision on each legal order's respective adequacy to the Rechtsstaatlichkeit understood as a synthesis of formal and material elements of what grosso modo is the democratic rule of law.

A good way of rounding off these enlightening perspectives into some of the sovereignty-related conceptual debates spurring from the European process of regional integration is S. Krasner's international relations' approach to test the fate of sovereignty à la européenne for the rest of the world. ${ }^{73} \mathrm{~S}$. Krasner adopts a bird's-eye realist view of the international chessboard by dividing the current states of the world in different categories depending on whether they share what he defines as the "analytically and empirically distinct" elements of sovereignty. These are broadly identified by Krasner to be those of "international legal sovereignty", "Westphalian/Vattelian sovereignty" and "domestic sovereignty" 74 which are not "always conjoined in practice". ${ }^{75}$ In mapping the contemporary world through these lenses, Krasner comes up with three great categories. The first of these categories is composed by the "modern world of conventional sovereignty" with around 84 states, including the great superpowers the US, China and Russia, all of which possess the three distinct attributes of state sovereignty. The second category, which Krasner terms the "post-modern world", comprises mainly all EU member states as the latter comply with both the criteria of "international legal" and "domestic sovereignty", but not with the Westphalian/Vattelian type of sovereignty. Finally, the third category is reserved for the "pre-modern world". Depending on the sources of reference employed to categorize both failed and badly governed states, this category, according to this author, comprises between 37 to 73 countries all of which possess "international legal sovereignty", but not "domestic sovereignty" and may or not possess the attributes of "Westphalian/Vattelian sovereignty".

Krasner's IR realist perspective constitutes a refreshing zooming out from the theoretical hermetic nooks and crannies of the historical, constitutional, legal-international and EU legal-based analysis presented in Sovereignty in Fragments around sovereignty, understood as the "provider of the dominant logic of appropriateness for organizing political life". ${ }^{76}$ Against this background, two further contributions by J. Lipping and A. Negri respectively push post-foundational political thought and post-modern philosophical speculation around the concept of sovereignty towards new extremes. J. Lipping, writing in a post-foundational vein, goes a step beyond the framework provided by the current debates on the fate of sovereignty triggered by the vaunted contemporary withering of the state, in order to "rethink sovereignty altogether outside the classical notion of the state". ${ }^{77}$ Lipping approaches the conceptual decoupling of which, since Bodin and Hobbes, has been the self-reinforcing "absolute centre of political thought and political practice" so as to embrace what he terms an on-going "major horizon shift in the meaning of social and political concepts". According to this author, engaging with the "growing non-correspondence between the

\footnotetext{
71 lbid., 171

72 lbid., 183.

73 S. D. Krasner, "The durability of organized hypocrisy", in H Kalmo and Q Skinner (eds) Sovereignty in Fragments. The Past, Present and Future of a Contested Concept (Cambridge UP, 2011) 96.

74 lbid., 96.

75 lbid., 97.

76 Krasner (2011), 96.

77 J Lipping, "Sovereignty Beyond the State" in H Kalmo and Q Skinner (eds) Sovereignty in Fragments. The Past, Present and Future of a Contested Concept (Cambridge UP, 2011) 186.
} 
old conceptual paradigm" and the post-modern condition's "changing institutional or social context" opens new ontological possibilities in the representation of the proper locus of "the political". This is one that the author identifies as framed by the "political parallax par excellence"; that is, the one provided by the "at once intimate and impossible" conceptual - and irreducibly dislocated - relationship of, respectively, Arendt and Schmitt with regard to "the political". This line of introspective abstract reflection leads Lipping to carve out a "certain conception of political space" that he suggestively calls öffentlichkeit ("the public"). This new space offers, according to Lipping, some prospects and opportunities for the concept of sovereignty as a carrier for a "new way of thinking about political matters, about the human condition, about being -in-the-world and living-together". The celebrated Marxist sociologist and political philosopher, A Negri in its turn approaches the question to "how to escape the fetish of sovereignty as the concept of government in modernity" 78 by delving into three perspectives that, according to this author, justify the consideration that sovereignty is in crisis within post-modern thought. These are, firstly, the perspective brought about by the biological transformation à la Foucault of the concept of sovereignty; secondly, the perspective on sovereignty which resulted from the application to the concept of the autopoietic approach and societal constitutionalism à la Luhmann and his followers; and, thirdly, the profound modification of the concept of sovereignty operated at the hands of the United Nations' legal experts. Negri penetrates these three perspectives in order to carve a new intellectual space for sovereignty at the interstices of what he terms government, exception and governance. So, "where do we find ourselves" (regarding sovereignty) "after the dusk" (to echo the editors' own words) "from the work of post-modern demystifications has settled"? ${ }^{79} \mathrm{M}$. Koskenniemi, in his conclusive chapter, approaches this question by pointing to the never-ending closure of the circle of deferrals of disciplinary discourse. ${ }^{80}$ Indeed, Koskenniemi concludes that "learning the different vocabularies of sovereignty is a useful act of enlightenment ("the sovereignty of reason")" and one that "will also make us more efficient users of those languages". ${ }^{81}$ However, Koskenniemi argues, although, by doing so, we may learn to be better equipped in the strategic use of the different languages of sovereignty, "we shall remain unable to tame and constrain sovereignty within definite terms". ${ }^{82}$ A similar conclusion seems to be shared by the editors themselves who also acknowledge that, instead of the obtainment of "an all-round view of sovereignty", what may, perhaps, be unveiled by inter-disciplinary dialogues from scholarly fields, which share a common fragmented nature, is a "jigsaw puzzle with pieces that simply refuse to fit together". ${ }^{83}$

Although many of the contributions to this highly complex book may not grant themselves easily to the reader, the truth remains that to navigate through the porous borders of compartmentalized academic knowledge in the pursuance of an even chimerical "all- round view of the concept of sovereignty" ${ }^{84}$ has the potential to lead to new types of enriching osmosis and intellectual synergies for all fields of reflective inquiry involved. This becomes apparent in the conclusive chapter of Sovereignty in Fragments in which Koskenniemi who in his post-2000s work, has often heralded a 'culture of formalism' in international law ${ }^{85}$ offers another an unsettling prescient on

\footnotetext{
78 See further A Negri, "Sovereignty between government, exception and governance" in H Kalmo and Q Skinner (eds) Sovereignty in Fragments. The Past, Present and Future of a Contested Concept (Cambridge UP, 2011) 205 current evolution of international law towards new International Relations-grounded vocabularies and empirical political science, See M Koskenniemi, 'Formalismo, fragmentación y libertad: temas kantianos en el Derecho
} 
the on-going evolution of a new understanding of "sovereignty". He does so by highlighting "how globalisation means the increasing authority of technical and economic vocabularies and systems of expertise that seek to manage global problems so as to attain optimally effective solutions' and by baptising these 'new forms of power-global, informal and legitimate'-as 'the new sovereignty.' 86 In highlighting this theme, Koskenniemi's chapter engages in a silent dialogue with the core-themes of both sovereignty and inter-disciplinarity that Sovereignty in Fragments shares with the second volume under review where J. Trachtman constructs a normative social scientific functionalist theory to attempt to bear on the future of international law.

\section{Back to the Future of International Law?}

In The Future of International Law. Global Government, $87 \mathrm{~J}$. Trachtman attempts the herculean task of trying to bridle the overwhelming character of our day and age by radiographing the present times through the construction of a comprehensive social science functionalist methodological perspective. Trachtman's reinterpretation of functionalism is addressed to give an answer to what he considers are the many contemporary exceptions to the Westphalian paradigm and - what he terms - its "centrepiece, untrammelled sovereignty". ${ }^{88}$ The author attempts to show that the Westphalian paradigm is bound to be replaced by what he terms the "social science functionalist paradigm". This is one that accepts that "the state is contingent, and that international law tends to constrain - indeed, to mould - the state on the basis of its functional efficiency". ${ }^{89}$ Trachtman's prediction of the evolution of such on-going paradigmatic shift is based on the gradual unfolding of a series of phenomena that he examines under the new lenses of an inter-disciplinary methodology which is rooted in new institutional economics (including constitutional economics). The phenomena to which Trachtman brings to bear his normative (and yet not teleological) social-scientific reinterpretation of functionalist and neo-functionalist approaches to international integration in order to produce a methodology with the aspiration to analyse integration on a global scale, include the examination of predictions of changing trends in areas such as globalization, economic development, demography, technology and democracy. His methodology also extents to the examination of the possible evolution of cooperation problems in selected functional areas such as those of cyberspace, human rights, international environment and health regulation, international finance, trade, intellectual property protection, migration and investment. Different techniques, including price theory, transaction costs economics, game theory, contract theory are brought together by Trachtman under comparative institutional cost-benefits analysis in a book that he makes an express point in defining as "welfarist" in approach. ${ }^{90}$ The predictive outcome of the application of such functionalist social scientific paradigm, which is one that understands the "sovereignty of states in utilitarian and contingent terms", ${ }^{91}$ is the "increasing production of international law and of organizational structures" (...) which, in the author's view, will increasingly "be seen to perform governmental functions". ${ }^{92}$

internacional actual', trans. Ignacio de la Rasilla 2 Revista Internacional de Pensamiento Político (2007) 209. Also published as M Koskenniemi, "Formalism, Fragmentation, Freedom: Kantian Themes in Today's International Law", 4 No Foundations. Journal of Extreme Legal Positivism (2007) 7.

86 Koskenniemi (2011) 239.

87 J P Trachtman, The Future of International Law, Global Government (Cambridge UP, 2013)

88 Trachtman (2013) 18

89 lbid.

$90 \mathrm{lbid}$. 17. In particular, the author points that "this book is welfarist, in the sense that I have tried to specify the circumstances under which citizens, generally operating through states or perhaps regional organizations, would determine to utilize international legal cooperation in order to improve their welfare"

91 Ibid.

92 lbid., 3 
The perception that "international law may grow in a way similar to municipal law", 93 which is the sense in which the author considers that "the future of international law is global government", 94 is, however, in Trachtman's view, obscured by both the descriptive and predictive inaccuracy of a "state-dominated understanding of global society". ${ }^{95}$ This "state-dominated understanding" of the world does not give enough space to the appreciation that "international law will grow to supplement the state as a form of government in a federal or divided powers sense". ${ }^{96}$ Trachtman, who is persuaded that "perceptions and ideas mediate institutional change" and that "any self-conscious law reform must be based on some degree of anticipation of future conditions" 97 implements his sophisticated analytical methodology with the purpose "to illuminate the utility of international now and in the future in order to influence perceptions of the need for international law". ${ }^{98}$

Chapters 2 to 4 set the ground for his general analytical template to analyse the role of international law in international cooperation problems. These chapters also cater for the consideration that is due to the analysis of the role of domestic politics in underpinning the state's role as a "dynamic aggregator of individual, group and coalitions preferences". 99 The linkage of this dual rational-framework which, respectively, examines the reasons for international law and the need to examine "domestic politics in order to understand why international law is made and why states comply with it", 100 to on-going trends in globalization, development, demography, technology and democracy is justified by the importance of predictions about these evolving factors as providers of "shocks to the existing equilibrium that change relative prices of different externalities, public goods, or other causes of international law". ${ }^{101}$ More specifically, Chapter 2 provides a "taxonomy of the types of circumstances that give rise to international cooperation, and the types of cooperation that seem better addressed through international law, as opposed to non-legal, or informal, cooperation". ${ }^{102}$ In particular, the author attempts to prove, in an argument, which is reminiscent of the late T Franck's early examination of international law compliance pull, ${ }^{103}$ that while "international cooperation can be useful under a variety of circumstances, including externalities, public goods, economies of scale and scope, and network externalities", 104 the added value of international law (when compared to non-legal approaches) is that the former can help to "address cooperation problems that involve strong incentives to defect"105 in real-world situations. In Chapter 3, the author engages with several contributions to the literature on the liberal theory of international relations on the domestic causes of adherence to and compliance with international law (including contributions by Gourevitch, Putnam, Moravcsik, Mo, Dai and others). Trachtman does so in order to adapt the Grossman-Helpman model of the lobbying process in international trade negotiations to account for the potential of functional transnational linkage of domestic Public International Law lobbies under a policy-exchange contractual theory of international law. Having examined the internal dimension, Chapter 4 preoccupies itself with the potential for change brought to international law by current

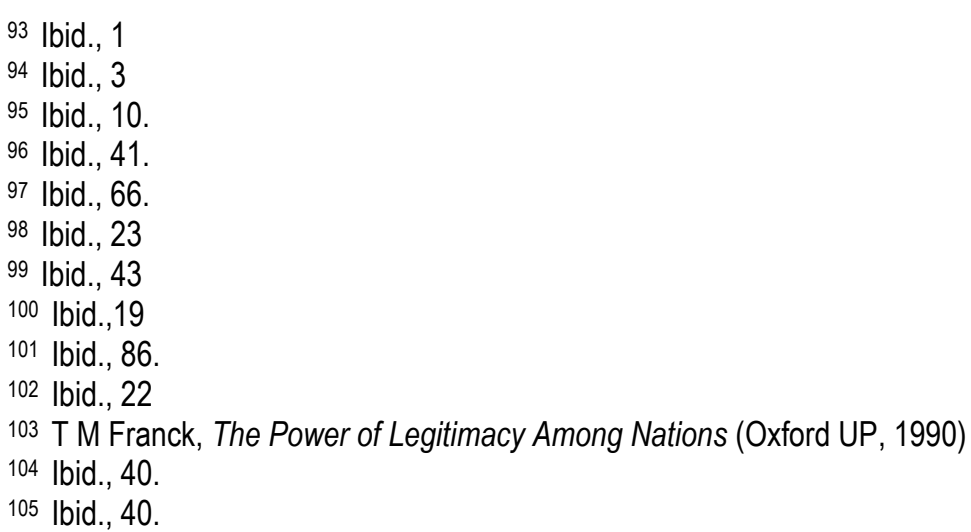


predictions on the evolving dimensions of globalization, economic development, demography, technology and democratization. The author's analysis is mainly based on positive predictions. These include so as, to provide some examples, the estimate that the growth of the "global middle class" will rise from 7.6 percent of the world's population $(440 \mathrm{~m})$ to $16.1 \%(1.2 \mathrm{~b})$ in the next decades. ${ }^{106}$ Another example is the predictive positive effects on demands for international cooperation produced by the "Haasian feedback loop" that operates between globalization and the demands it places on international law ${ }^{107}$ in a scenario influenced by the prediction of more "cosmopolitan outlooks and more cultural and political homogenization resulting from demographic changes and migration waves" 108 and the prediction that 2052 the majority of countries of the world "will be governed democratically ${ }^{109 "}$ ". In a nutshell, Trachtman considers that these series of anticipated future developments will have "important impacts on the demand and supply of international law"110 in the horizon that lies between 2012 and 2062.

Chapters 5 and 9 examine in their turn different cooperation problems as they arise in different functional sectors. This functional sectorial extension to a selection of different areas of international legal scholarship serves the author to illustrate the analytical methodologies developed in chapters 2 and 3 within the horizon provided by the changing scenario of influencing global phenomena examined in Chapter 4. The aim of these sectorial chapters is to suggest legal and organizational responses that will cater for both contemporary and future greater demand for international law. According to the author, the challenges and opportunities for international law and global government brought about by the areas of cyberspace and cyber-security, international human rights, environmental protection and public health, global regulation of finance and trade, intellectual property, migration and investment whereas they call "for a specific type of international legal response"111 also involve common themes. Prominent among these common themes is that all of them show the inability of a "state-dominated understanding of global society" to manage and apprehend them in an optimal manner. Each of the sectorial chapters involves the advancement of the methodological agenda of Trachman's "functionalist social science paradigm" in international law to several functional areas of international legal development. For instance, Trachtman considers that current international human rights' expert knowledge can benefit if those invested in this field of knowledge become more familiar with a "preference-based analytical approach to the demand and supply of international human-rights law". 112 Another example is that international environment lawyers and experts on international public health can benefit from examining international cooperation problems in areas such as "infectious disease, ozone-layer protection and climate change"113 through the application of a series of analytical templates that give salience to the externalities and public good aspects of these areas. Finally, Chapters 10 and 11 suggest methods of analysis of the challenges emerged from the increasing densification of international law and the risk of collision - but, also opportunities for positive synergies - which emerge from with the contemporary complexity and fragmentation of the international legal order. The analytical framework that Trachtman provides in Chapter 10 is oriented to help to account for these challenges "first as issues of horizontal allocation of jurisdiction, second as issues of vertical allocation of jurisdiction and, third as horizontal allocation of jurisdictions among international rules and organization". 114 This

\footnotetext{
106 Ibid., 76

107 lbid., 73-74

108 Ibid., 80

109 lbid., 82

110 lbid., 83

111 lbid.,19

112 Ibid., 121

113 lbid., 149

114 lbid., 251
} 
perspective is complemented, in Chapter 11, by an explanation of how the present state of international law is bound to generate an increasing demand of international legal constitutional norms and processes - introducing hierarchy and order or, at least. a set of coordinating mechanisms - as a corollary to the increase of supply of international legal rules and of the development of institutions of legislation, adjudication and enforcement that are bound to grow functionally as the demand for international law increases in the future.

Trachtman's book is a highly dedicated scholarly tour de force. It attempts to foster a truly methodological colonization of international law through the advancement of an economic rationality and an analytical tool-kit. These, in the author's view, have much to contribute to the management of the present and the future of international law. The contemporary scholarly allure of the phenomena Trachtman examines is reliant on a series of contemporary factors, and the methodology he employs is built on a specialist refinement of empirical social sciences and economic rationality. Against this background, it may, nonetheless, be worthwhile recalling that the twin phenomena of functional diversification and fragmentation and the accompanying constitutionalization of the international legal order - both of which serve the author to predict that the future of international law is global government in the sense described that "international law may grow in a way similar to municipal law" 115 pursuant to the dynamics of cross-functional integration - are, in themselves, the logical outcome of a structural tendency sprung up from the liberal theory of politics underpinning the domestic liberal state. ${ }^{116}$ This is a structural tendency that became inextricably enshrined within the genealogy of contemporary international law when the prototypical institutions of the domestic constitutional liberal state were transposed, as part of the First World War peace-settlement, for the first time, with permanent character, to the international plane.117 In essence what Trachtman attempts in his book is to flesh the bones of this structural tendency of the international legal order through a social-scientific reinterpretation of functionalist and neo-functionalist approaches to international integration that is aimed to produce a methodology with the aspiration to foster processes of "optimal" integration through different sectors on a global scale. This aim is, invariably, accompanied in his work by the advancement of a methodological agenda which, as M Koskenniemi who examined "the novel jurisprudentia universalis as a technical and empirical science" 118 has shown, is not without parallels in the past of the discipline itself. However, Trachtman, restricts his normative functionalist social science interest to methodologically graduate only the eyes of one of the faces of Janus - and, as it can be expected, this is the face of Janus that looks to the future of international law. The almost inexistence of any trace of historical analysis in the author's exhaustive methodological tour de force does, thus, warrants a brief comment from the perspective of the other face of Janus, that is, the face of Janus that looks to the past of international law. This is especially relevant at a time when international legal scholarship appears to be in creative tension between the opposite poles of, on the one hand, its intellectual

115 Ibid., 1

116 See A. Carty, "Critical International Law: Recent Trends in the Theory of International Law", 2 European Journal of International Law, no.1, (1991) at 66, 66. ("The discipline is governed by a particular historically conditioned discourse which is, in fact, quite simply, the translation onto the international domain of some basic tenets of liberal political theory").

117 In comparing the difference of conceptualization which existed between the founders of the Institut de Droit International and those who drafted the Treaty of Versailles, Koskenniemi echoed this in clear terms :"the key difference between the way the men of 1871 had looked at the international unions and conferences and the way the lawyers of 1919 conceptualised the League and other international organisations lay in the domestic analogy adopted by the latter». See M. Koskenniemi, "Nationalism, Universalism, Empire: International Law in 1871 and 1919 " Columbia University, April 2005.

118 Koskenniemi (2007) 9. See also M Koskenniemi "Miserable Comforters: International Relations as New Natural Law" 15. 3. European Journal of International Relations (2009) 395 
colonization by an extremely sophisticated - and overall enlightening - IR/IL literature and, on the other, and an intra-disciplinary historical turn in international law. In this context, it may be, indeed, worthwhile recalling, in paraphrasing Q. Wright, that "in their emphasis on contingency [historians] provide a healthy antidote to the overenthusiastic social scientist". ${ }^{119}$ Moreover, a transposition of Wright's views to the history of international law might also help one to assess the potential that the contribution of the historians of international law can make to the future of international law itself. In particular, such a contribution, borrowing from Wright's own words, would be that of making it grow more appreciative of a "balanced sense of continuity and change, of uniqueness and repetition, of causation and contingency and of choice and standards" (...) by helping it to "better realize the complexity and uncertainty of human affairs, the many factors to be considered in making judgments, the dangers of abstraction, of dogmatism, of prediction, of action, and of inaction" (...) and to "better understand the abundance and variability of human values and the opportunities as well as the insecurities of any situation". 120

\section{Conclusion}

These two books Sovereignty in Fragments. The Past, Present and Future of a Contested Concept and The Future of International Law. Global Government may not grant themselves easily to all international law audiences. This is particularly so in view of the post-modern thought intricacies in what some of the authors of Sovereign in Fragments indulge themselves, and because of the economic-based-rationality and analytical methodology, including game-theory, price theory, transaction costs economics, game theory and others contained in The Future of International Law. However, the truth remains that to navigate through the porous borders of compartmentalized academic knowledge in the pursuance, as in Kalmo and Skinner's edited collection, of perhaps a chimerical "all- round view of the concept of sovereignty"121 in the fragmented fields of contemporary social sciences, or, as in Trachtman's book, to finely adapt the lenses of other disciplines, vocabularies and methodological tools to both influence and assess the future of international law, leads to new types of both anti-dogmatic osmosis and intellectual synergies for all fields of inquiry involved. Moreover, in spite of the sophisticated methodological complexity which lies between the two extremes of cutting-edge types of scholarship contained in these books, both works should, be praised from having added new layers of complexity and interdisciplinary analysis to the great collection of international lawyers' reflections on its locus classicus: state sovereignty. At the end of the day, the truth remains that we cannot, probably, predict, with any degree of scientific certainty, what the future will be, even if new methodological lenses are developed to influence its unfolding in accordance with a basic structural tendency of the contemporary international order, any more than we can aspire to come up with a perfect grasping of an essentially contested concept like sovereignty, even if we rely on the best that each discipline has ever distilled about it has to offer us. But, perhaps, that we can, nonetheless, anticipate, with a considerable degree of certainty, that international lawyers shall continue to elaborate their stories, now in a growingly interdisciplinary field, around the locus classicus of international law aware that it is the hope that these stories bring for them (and others) to survive to see another sunset what shall, ultimately, keep flowing the tales of the thousand and one nights of Westphalia. ${ }^{122}$

\footnotetext{
119 Q Wright, A Study of War (2 vols) (Chicago UP, 1955) 87.

120 Ibid., 89

121 Kalmo \& Skinner (2011) 24

122 For new bibliographical additions, see: I De la Rasilla, "History of International Law, 1550-1700" in A. Carty, Ed.) Oxford Bibliographies of International Law (2013), and I De la Rasilla, "Medieval International Law", in (A. Carty, Ed.) Oxford Bibliographies of International Law (2014). See also, Anonymous, Tales from a Thousand and One Nights, transl. N. J. Dawood (Penguin Classics, 1973)
} 
Sovereignty through the Inter-disciplinary Kaleidoscope - unedited version

Ignacio de la Rasilla del Moral @ Edited version available at 84 Nordic Journal of International Law (2015) 130-152 